\title{
Tracer Study Analysis of Vocational Education in Politeknik Negeri Bandung With Exit Cohort as an Approach
}

\author{
Yeti Nugraheni*, Susilawati Susilawati, Sudrajat Sudrajat, Angki Apriliandi \\ Politeknik Negeri Bandung \\ Bandung, Indonesia \\ *yeti.nugraheni@polban.ac.id
}

\begin{abstract}
Tracer study is a study of graduates of higher education institutions. This study is able to provide a variety of information that is useful for the purposes of evaluating the results of higher education and can be used to improve and guarantee the quality of it. The general purpose of this study is intended to receive input from respondents to obtain the characteristics of the quality of the higher education institution. The approach taken in this study is to use the exit cohort as the target respondent, with the census method carried out after 2 years of graduation. This approach is taken in accordance with the characteristics of the education system at the polytechnic is in the form of packages so that the graduation year is the right choice. The research object is a graduate of Diploma III program and Diploma IV program in Politeknik Negeri Bandung. In this study shows that factors such as the transition in the world of work, maps of graduate activities in the world of work, graduates' horizontal and vertical alignment maps, gap of graduate competency and demands of the world of work show good results, namely an increase in several variables, especially for two respondent targets which are used as approaches.
\end{abstract}

Keywords—analysis, tracer study

\section{INTRODUCTION}

Higher education requires evaluation and reciprocity to improve education systems and management. However, awareness and concern for the importance of evaluating the results of higher education in universities is still quite low. The outcome of higher education are the knowledge, abilities and competencies of college alumni needed to enter the workforce. These results with the conditions when alumni undergo work early in their careers are things that are needed for universities to improve their education systems and management. The need to know the track record of alumni and the relationship of higher education with work is the basic concept in the tracer study research.

Tracer studies or "follow up" surveys are studies of graduates of higher education institutions. This study is able to provide a variety of information that is useful for the purposes of evaluating the outcome of higher education and can be used to improve and guarantee the quality of the higher education institutions concerned. Tracer study is also useful in providing important information about the relationship between higher education and the world of professional work, assessing the relevance of education, information for stakeholders, and the completeness of requirements for higher education accreditation. Information on tracer study results if further processed can provide high feedback for universities.

Polytechnic is a university that organizes vocational education in various clusters of science and / or technology. In general, education in Polytechnic has special characteristics such as tuition fees in packages. The tuition load that must be taken by a student each semester is arranged in packages so that students must take all the courses that have been determined in the current semester [1]. This form of package resulted in relatively the same study period for polytechnic students, namely 3 years for diploma level three and 4 years for diploma level four except for certain cases due to academic leave, suspension and a period of repetition for students with problems. This particular role will result in data collection and processing techniques in tracer study being different from other forms of higher education than polytechnics.

The results of the tracer study analysis are expected to show the outcome, output, process of forming competencies, as well as socio-biographical information of graduates from a higher education institution [2]. Many factors and variables can be used in tracer study analysis, but in this study the results of tracer studies are expected to be able to find out about polytechnic graduates, especially Politeknik Negeri Bandung in terms of transition in the world of work, maps of graduate activities in the world of work, horizontal and vertical alignment maps of graduates, and a map of graduate competency gaps and the demands of the working world that will be very useful for getting self-portraits.

\section{TRACER STUdy INSTRUMENT}

Devices or instruments in the tracer study activities other than the core questionnaire also required several things, including:

\section{A. Institutional}

Tracer study is to be carried out well, namely: institutionalizing, continuing and continuous improvement [3]. In many universities, tracer study activities are one of the 
career centre institution programs. Tracer studies should be carried out by institutions that link between universities and the business world and industry, not carried out by certain study programs or departments in universities. Tracer study at Politeknik Negeri Bandung is carried out by polytechnic institutions rather than study programs or majors.

\section{B. Core Questionnaire}

The questionnaire adopted from several core questionnaires that were tailored to the needs of each campus. The international core questionnaire is taken from the Unit race Core Questioner, the core Indonesian questionnaire is taken from the Indonesia Tracer study Network (INDOTRACE). From the mechanism, the DIKTI (Pendidikan Tinggi) has established a questionnaire which is the core question of tracer study where each university must include the question in its survey. Nevertheless, universities can add questions in accordance with the interests but are not allowed to reduce or change the core questions [4]. This is to guarantee the standardization of instruments for the benefit of compilation and comparison of national data. The questionnaire used at the Politeknik Negeri Bandung used a questionnaire from DIKTI by conducting several adaptations according to the tracer study needs of the Politeknik Negeri Bandung. The mechanism in determining the tracer study questionnaire also involves departments and study programs so that they do not overlap and or overlook.

\section{Infrastructure and Human Resource}

To conduct a census survey, supporting facilities must be prepared, including: telephone devices, computers and internet networks, and other supporting facilities such as workspaces, data base servers. Human resources are needed in the implementation of tracer studies, especially teams and / or permanent staff who are trained / trained so that they have insight, knowledge and skills and analytical skills and have the ability to make reports about tracer studies.

\section{Methodology}

Data collection methods in the online tech era should use online media because it is effective, efficient and practical. However, various methods of data collection can also be carried out (face-to-face interviews, telephone interviews, postal letters, and email). In statistics there are two types of data collection methods, called census and sampling methods.

Data collection methods can be done through census / sensation or sampling. Census is a way of collecting data when all population elements are investigated one by one. The data obtained is the result of census processing referred to as actual data (true value), or often also called parameters [5]. While Sampling is a method of collecting data if the investigated is a sample of a population. The data obtained from the sampling results are estimated values. So, if only 100 people will be investigated by 10 people, the results of the investigation are an estimate.

\section{E. Approach}

The approach taken for the implementation of tracer studies can be done with two approaches. This approach will determine the target of respondents in building a database. The first is the target respondent based on the graduation force approach or known as the exit cohort. In exit cohorts entering college may be in a different year, you can also enter college in the same year but have the same graduation year. The second approach is entry cohort or respondent's target based on the incoming class, which is to enter in the same year but can have a different graduation year. Cohort is a group used as part of a research study. This group consists of people who have similar characteristics (for example, the year of entry or the same graduation year). If the tracer study uses the force data (the same year of entry) it is called the Entry Cohort and if you use the graduation data, it is called the Exit Cohort. The year used in this tracer study is generally 1-3 years after graduation [6]. While Schomburg stated that tracer study is generally carried out in the 1st to 2 nd year after graduation [7]. Both of these approaches can be used for the implementation of tracer studies, although what is commonly used is a tracer study based on the Exit Cohort which is sometimes called a cohort. And the year taken is usually the 2nd year after graduation [4].

\section{MeTHODOLOGY}

The research method used in this study is a survey method with descriptive quantitative analysis. There are two main stages in this study: data collection and data analysis.

The most important thing in tracer study is data collection. Data collection in this study was conducted using census methods. The census survey involved all (100\%) college graduates in the year of the cohort that was followed.

The approach taken in this study is to use the exit cohort as the target respondent. Census is carried out after 2 years of graduation. In accordance with the characteristics of the polytechnic education system in the form of packages so that the graduation year is the right choice. The research object is a graduate of Diploma III program and Diploma IV program of Politeknik Negeri Bandung, while for Diploma II programs and master programs it is not included in the census. Census data is taken in 2017 and 2018. Respondents for 2015 graduates are censuses conducted in 2017 while respondents for 2016 graduates are censuses conducted in 2018. Initial inventories are conducted by looking at the latest data held, but checking is also done to obtain valid home address, cell phone and e-mail data. The number of eligible study programs consists of 14 Diploma IV Study Programs and 18 Diploma III Study Programs. Census is carried out via the internet through the page penelusuranalumni.polban.ac.id

After the data is collected, then the data is ready to be analysed. The variables analysed included emphasis on learning methods (including lectures, demonstrations, participation in research projects, internships, practicums, fieldwork, and discussion), the transition period from starting looking for a job to getting a job, current jobs including salary, vertical alignment and horizontal that is about the relationship between the field of study and work and also competences (among others: Knowledge in the field or discipline, 
knowledge outside the field or discipline, general knowledge, English ability, internet skills, computer skills, critical thinking, research skills, learning ability, ability to communicate, work under pressure, time management, work independently, work in teams / collaborate with others, ability to solve problems, negotiation, ability to analyse, tolerance, ability to adapt, loyalty, integrity, working with people of different cultures as well as background, and leadership). Besides that, the general characteristics of respondents such as gender, GPA and study program will also be presented.

\section{RESULTS AND DISCUSSION}

Respondents targets used as census in 2017 and 2018 were graduates in 2015 and 2016, totalling 1442 alumni who graduated in 2015 and 1539 alumni who graduated in 2016, consisting of 18 study program for D3 and 12 study program for D4.

The respondents targets who are tracer, $70 \%$ response rate is obtained which will be the basis of the discussion in this study or 935 for respondents who passed in 2015 and 1007 for respondents who passed in 2016. Variables and factors obtained when tracer studies amounted to more than 50 variables, but only a few will be discussed in this research. The pre-work factors seen in this study is gender, GPA and study program. The condition of alumni seen from gender that gender is dominated by male gender, both for 2015 graduates and 2016 graduates for D3 and D4 programs with an average difference of 120 people.

Graduates achievements can be known through the GPA (Grade Point Average). The figure 1 shows that graduates in 2015 and graduates in 2016 have the highest population GPA between 3 and 3.5 for all programs, both D3 programs and D4 programs. $49 \%$ of D3 programs and $58 \%$ for D4 programs that passed in 2015 had a GPA of between 3 and 3.5, while in 2016 they were $49 \%$ for D3 programs and 53\% for D4 programs. When viewed by gender, the female has a GPA with an average greater than the male GPA.

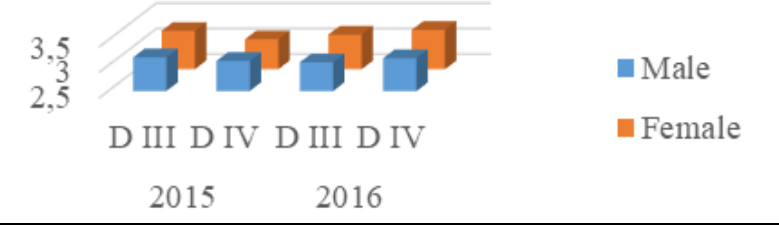

Fig. 1. Average GPA based on gender.

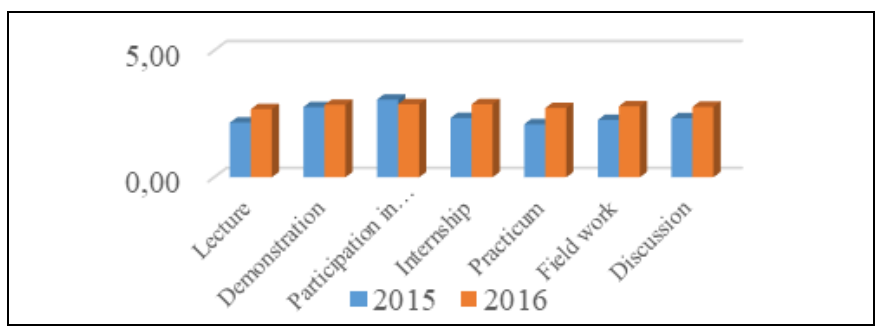

Fig. 2. Learning methods.
The figure 2 shows that the average learning method that is considered to have the greatest emphasis is practicum, followed by field work, discussion and lectures. While other learning methods are considered to still receive considerable emphasis, although not as big as practicum, field work, discussion and lectures. Whereas if viewed based on engineering and non-engineering study programs, the learning method that gets the most emphasis on engineering study programs is practicum. And for the non-engineering study program the method that gets the most emphasis is lectures.

Respondents made various efforts to get their first job. Many of these businesses began before graduation. Based on tracking results, the majority of respondents of more than $50 \%$ did from one month before graduation, then as much as more than $40 \%$ one month after graduation, the rest did not seek work on the grounds of continuing education and marriage.

In order to get a job, respondents chose the internet to get job info. Considering the large number of graduates who are looking for work, other alternatives or other methods are taken, such as searching for information from career development offices, applying without vacancies, brochures and others as shown in the graph below. Another interesting thing besides the internet, is a career centre which can be used as a place to find information on job openings quickly. The career centre in this study (Politeknik Negeri Bandung) is called JPAC (Job Placement Assessment Centre) which is the main breaker for many graduates in the business world. Besides that, it turns out that the way to find a job by utilizing relationships still has positive results.

The average time to get first job before graduating is more than 1 month, with a maximum of one year before graduation, this is partly because of working as an entrepreneur and an intern. While the time to get the first job after graduation is a maximum of 20 months for respondents who graduated in 2016 and 36 months for respondents who graduated in 2015. On average to get the first job after graduation is more than three months. The table 1 shows the time needed to get the first job.

TABLE I. The Time NeEDED to Get The First JoB

\begin{tabular}{|l|l|l|l|l|}
\hline $\begin{array}{c}\text { The Time } \\
\text { Needed To } \\
\text { Get The } \\
\text { First Job }\end{array}$ & \multicolumn{2}{|c|}{$\begin{array}{c}\text { BEFORE Graduating } \\
\text { (Month) }\end{array}$} & \multicolumn{2}{c|}{$\begin{array}{c}\text { AFTER Graduating } \\
\text { (Month) }\end{array}$} \\
\hline & $\begin{array}{c}\text { Graduated } \\
\text { in 2016 }\end{array}$ & $\begin{array}{c}\text { Graduated } \\
\text { in 2015 }\end{array}$ & $\begin{array}{c}\text { Graduated } \\
\text { in 2016 }\end{array}$ & $\begin{array}{c}\text { Graduated } \\
\text { in 2015 }\end{array}$ \\
\hline Max & 9 & 12 & 20 & 36 \\
\hline Min & 1 & 0 & 0 & 0 \\
\hline Average & 1.73 & 1.67 & 3.73 & 3.08 \\
\hline Modus & 1 & 1 & 1 & 1 \\
\hline
\end{tabular}

The condition of the respondent when conducting a tracer study, the majority of respondents graduated in 2015 said they were working (76\%), while the rest $(24 \%)$ did not work for several reasons. Compared to 2015 respondents who graduated in 2016 the percentage who stated work experienced a $5 \%$ increase of $81 \%$, while those who did not work were $19 \%$. 
Respondents who did not work explained the reasons as shown in figure 3 (a) and (b): respondents said they were still studying / continuing their professional or postgraduate studies, were looking for work, married, busy with family and children, etc., such as being sick and having just finished education.

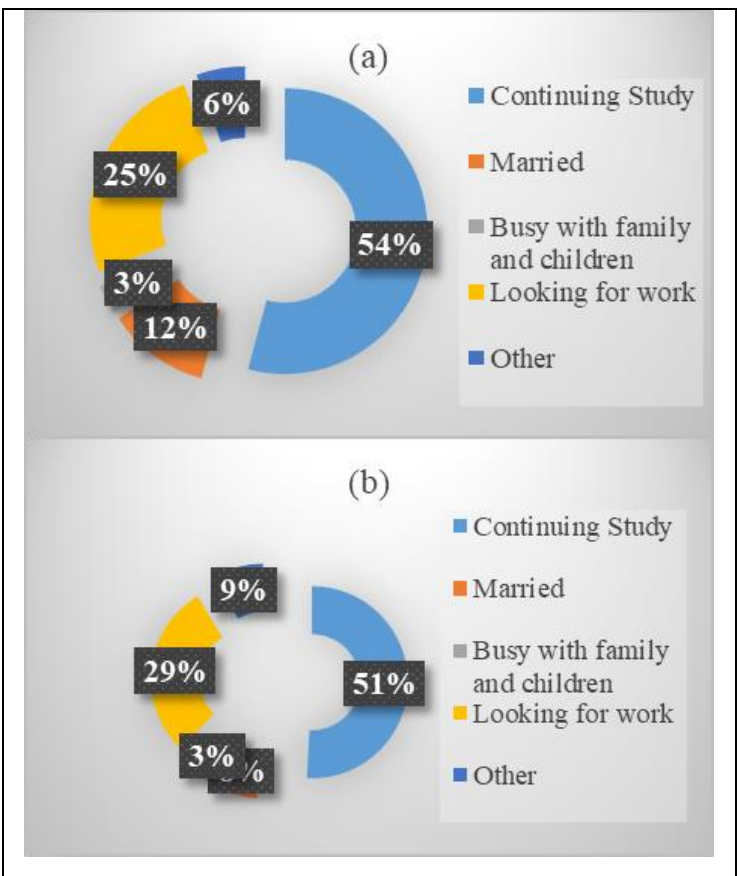

Fig. 3. Reason for not working (a) 2015 (b) 2016.

The type of work or agency where the respondent works is currently categorized into 3 choices, namely government agencies (including BUMN/Badan Usaha Milik Negara), private companies, and entrepreneurs both self-employed and own companies. Figure 4 (a) and (b) shown most respondents worked in private companies as many as $64 \%$ for respondents graduated in 2015, and 67\% for respondents in 2016. While as many as $26 \%$ for respondents in 2015 and $22 \%$ for respondents in 2016 who worked in government agencies. As for those who choose entrepreneurship there are $6 \%$ of respondents.

Based on income they have different income. The highest and lowest income works as an entrepreneur or company. Most respondents write income of Rp. 3 million. Based on the gender of the respondents income can be seen as the table 2 . From the table 2 male income is greater than female income.

TABLE II. INCOME RESPONDENTS

\begin{tabular}{|l|l|l|l|l|l|l|}
\hline \multirow{2}{*}{ Income } & \multicolumn{3}{|c|}{ Respondents Graduated 2015 } & \multicolumn{3}{c|}{ Respondents Graduated 2016 } \\
\cline { 2 - 7 } & \multicolumn{1}{|c|}{$\boldsymbol{A l l}$} & Female & Male & \multicolumn{1}{c|}{ All } & Female & Male \\
\hline Max & 40000000 & 20000000 & 40000000 & 20000000 & 10000000 & 20000000 \\
\hline Min & 500000 & 500000 & 500000 & 880000 & 600000 & 1000000 \\
\hline Average & 4469296 & 3916482 & 4959257 & 4546911 & 3993726 & 5011862 \\
\hline Modus & 3000000 & 3000000 & 3000000 & 5000000 & 3000000 & 5000000 \\
\hline Median & 4200000 & 3500000 & 4800000 & 4250000 & 3800000 & 4800000 \\
\hline
\end{tabular}

If income compared with GPA and gender, the results are interesting, that the highest GPA is obtained by female and the average GPA of female is greater than male but not with income. Male income is greater than female although when viewed from the average GPA, from the table 3 shown that male GPA are lower than female GPA.

TABLE III. GPA OF RESPONDENTS

\begin{tabular}{|c|c|c|c|c|c|c|}
\hline & \multicolumn{3}{|c|}{$\begin{array}{l}\text { Respondents Graduated } \\
2015 \\
\end{array}$} & \multicolumn{3}{|c|}{$\begin{array}{c}\text { Respondents Graduated } \\
2016\end{array}$} \\
\hline & All & Female & Male & All & Female & Male \\
\hline Max & 3.95 & 3.95 & 3.86 & 3.92 & 3.92 & 3.87 \\
\hline Min & 2.2 & 2.27 & 2.2 & 2.13 & 2.28 & 2.13 \\
\hline Average & 3.13 & 3.23 & 3.04 & 3.92 & 3.18 & 3.11 \\
\hline Modus & 3.2 & 3.2 & 3.1 & 3.92 & 3.11 & 3.37 \\
\hline Median & 3.12 & 3.23 & 3.04 & 3.92 & 3.19 & 3.11 \\
\hline
\end{tabular}

Alignment between study fields and respondent's work is seen in the figure 5 (a). The percentage which states very closely is $30 \%$ (respondents passed 2015) and $27 \%$ (respondents passed 2016). Not much different from the respondents who stated closely and quite closely. The $15 \%$ of respondents in 2015 stated less closely and $7 \%$ said they were not close at all. While respondents in 2016 stated that $16 \%$ were less tight and 9\% said they were not close at all.

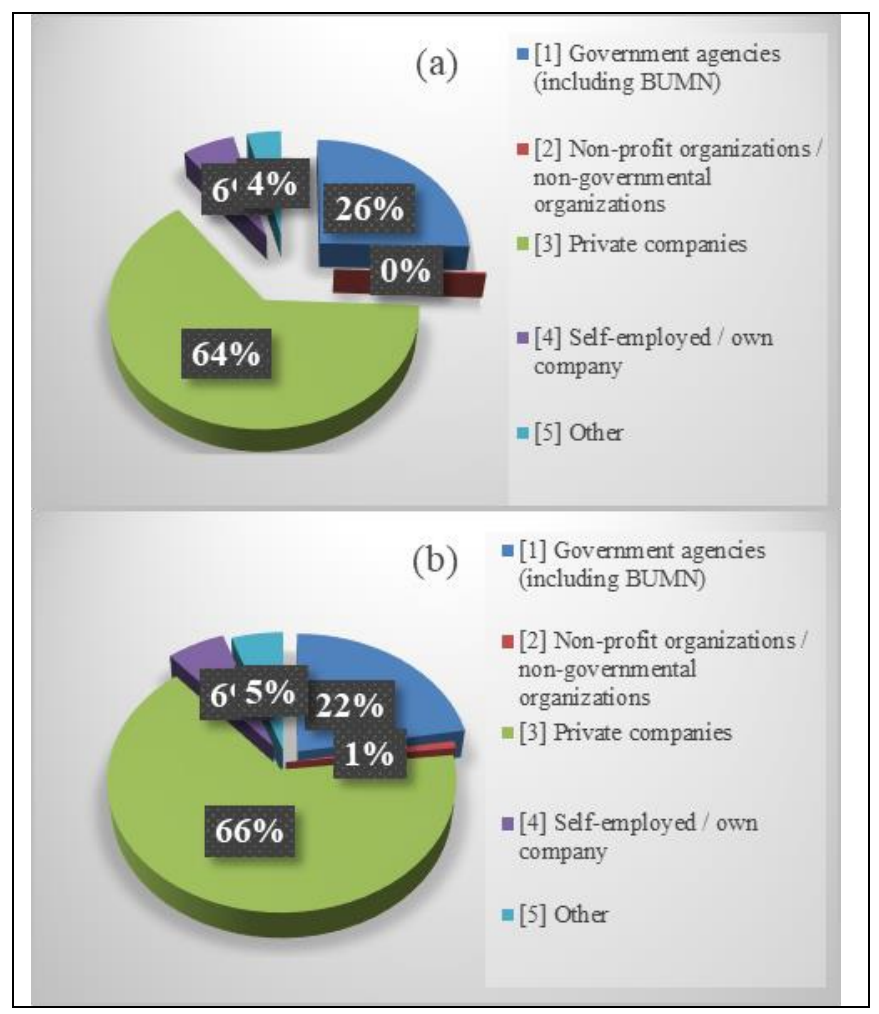

Fig. 4. Type of company (a) 2015 (b) 2016.

The figure 5 (b) illustrates the percentage of alignment of education levels with the work of respondents graduating in 2015 is now in line with the education level of $59 \%$ for program D3 and $74 \%$ for program D4. Whereas respondents who graduated in 2016, 58\% for program D3 and 67\% for program D4 stated in accordance with their education. So that the graduates of the program D3 study program work in accordance with the work for program D3 graduates and the 
program D4 study program respondent work in accordance with the work for program D4 graduates.

As many as $34 \%$ for program D3 and $10 \%$ for program D4 respondents passed in 2015 stating if the respondents worked at a higher level. This stated that if the graduates of the D3 study program then the work carried out is at the D4 level and graduates of the D4 study program, the work carried out is at the level of S2. As for as much as 2\% for D3 program and 9\% for program D4 respondents graduating in 2015 stated their jobs were of a lower level. While respondents passed in 2016 at $2 \%$ for program D3 and $13 \%$ for program D4 stated their jobs were of a lower level. Respondents who stated that they did not need higher education because the respondents did not work needed special skills or respondents were entrepreneurs.

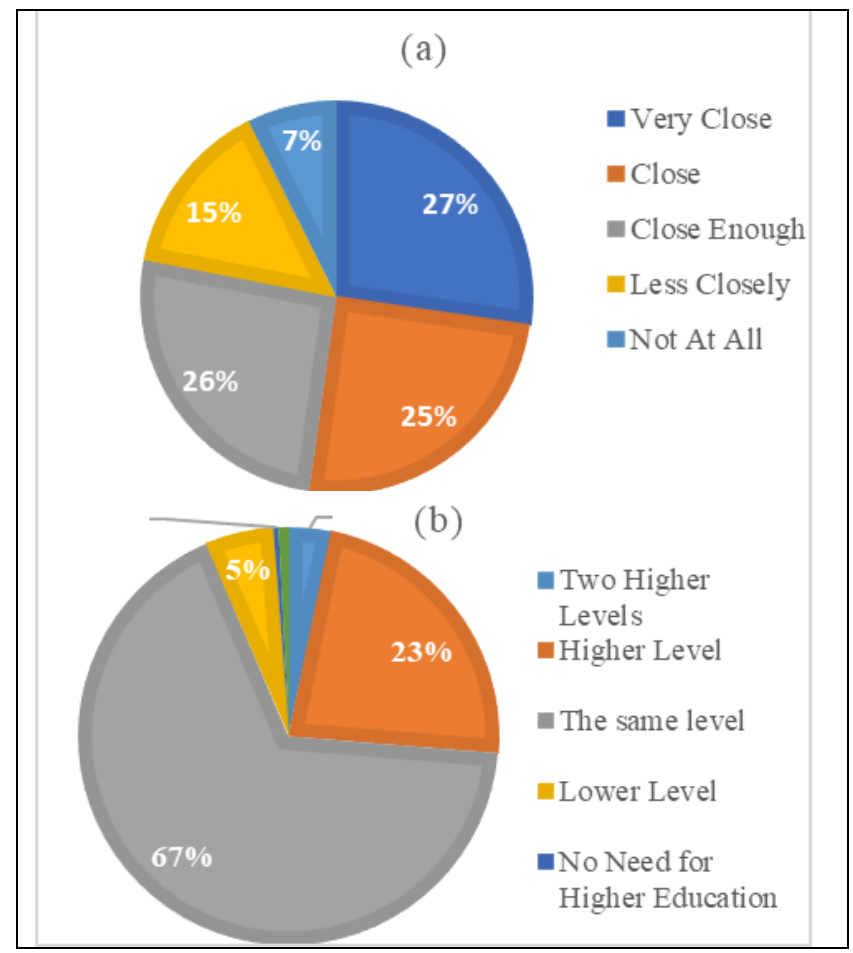

Fig. 5. Suitability (a) fields of study and work (b) suitability of education level.

Regarding the harmony between the education and work of the respondent, there are several reasons why the respondent took the job even though it was not in accordance with his education. Some reasons include the figure 6 . The three highest reasons are because the work obtained has good career prospects, the current job is more attractive and due to not getting the right job. When the results were further reviewed, $65 \%$ of the engineering program and $35 \%$ of the nonengineering programs for the respondents passed in 2015 while the respondents passed in 2016 at $42 \%$ of non-engineering and $58 \%$ of the engineering stated that they did not get the right job.

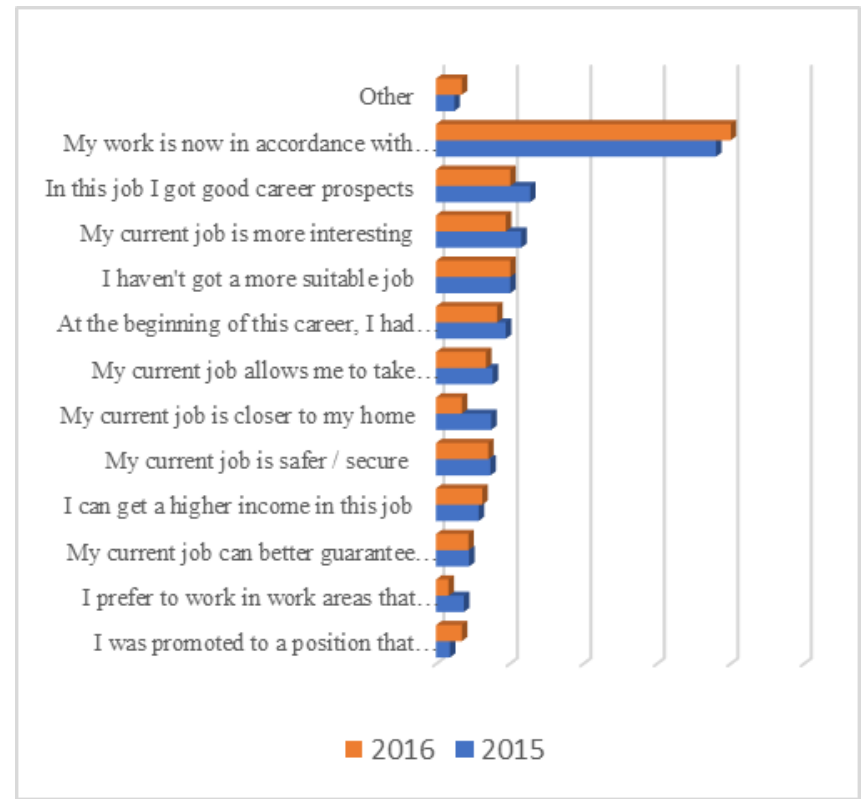

Fig. 6. Reason for taking the current job.

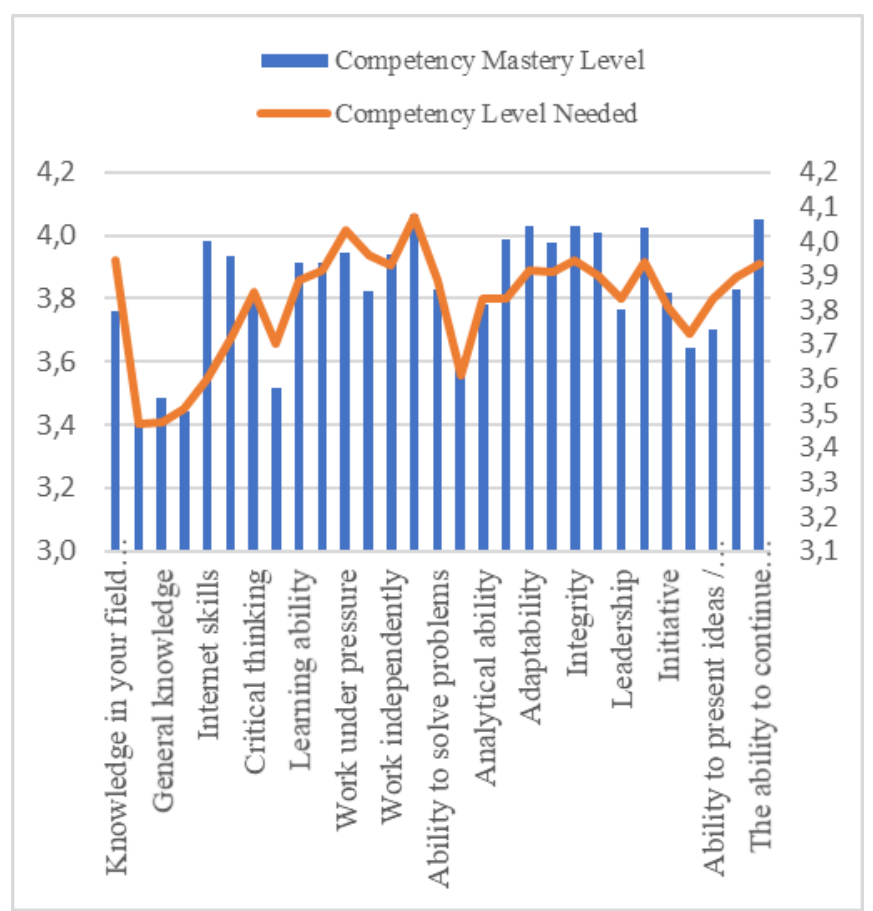

Fig. 7. Average mastery of competencies.

Based on competence, tracing the study was carried out by comparing the mastery of respondents competencies mastered at the time of graduation with the competencies needed in the work in accordance with the contribution of universities. Based on this, the average respondent's mastery and what is needed in the job are considered sufficient. Mastery that is considered the highest by respondent is the mastery of the ability to continue lifelong learning, the ability to hold responsibilities, work with people of different cultures and backgrounds, integrity, loyalty, adaptability, tolerance, working in teams / cooperating with others and internet skills. While the lowest assessed mastery is the ability of knowledge outside the field or discipline, general 
knowledge and English ability. Respondents considered that the most needed competencies when working were competencies regarding working in teams / working with others with an average of 4.1. Following other competencies that are badly needed is working under pressure and ability to hold responsibility.

The Average Mastery of Competencies of Respondents Who Are Mastered When Passed with Competencies Required in Employment in Accordance with Higher Education Contribution can be seen from figure 7 .

\section{CONCLUSION}

Based on data from the tracer study by using exit cohort in the 2015 and 2016 graduating years with the Politeknik Negeri Bandung case study, it shows that many things can be explored, among others in terms of transition in the world of work, maps of graduate activities in the world of work, horizontal and vertical alignment maps of graduates and map the gap in graduate competencies and the demands of the workforce.

Transition to enter the workforce is indicated by several variables, including GPA, gender and competence. Based on the results of the tracer study data, it was shown that there was an increase in the number of response rates and the average GPA of graduates. Likewise, the map of graduate activities in the world of work compared to respondents in 2015 there was an increase of $5 \%$ in the number of employed respondents who passed in 2016 from $76 \%$ to $81 \%$. Salaries obtained by respondents also increased on average compared to the previous year (2015). Likewise, the alignment between the field of study and work, from the results of the study shows respondents with the 2016 graduating year get more jobs that are in accordance with the subject of study.
Whereas the alignment of education level with the work of the respondents graduating in 2016 was a difference compared to the previous year (2015), especially for the D4 program, namely experiencing a decrease in the percentage for the same level of education. For the reason why the respondent does not get a job that is not in accordance with his field at most, that is not getting a more suitable job and the current job has good career prospects. To map the gap in graduate competencies and the demands of the work world, the average difference is only 0.1 , so that the competencies acquired during college can be said to be in accordance with the competencies of the demands of the workforce.

\section{REFERENCES}

[1] Politeknik Negeri Bandung, Peraturan Akademik Politeknik Negeri Bandung, 2012

[2] Tim Redaksi Kopertis V, Warta Kopertis edisi Desember 2014, Tracer Study Sebagai Cermin Diri Institusi Perguruan Tinggi, Yogyakarta, 2014 .

[3] B.S. Budi and A. Dinan, Report Tracer Study ITB 2017, ITB Career Centre, Bandung, 2015.

[4] Tracer Study, Direktorat Jenderal Pendidikan Tinggi Kementerian Pendidikan dan Kebudayaan, [Online] Retrieved from: http://pkts.belmawa.ristekdikti.go.id

[5] J, Supranto, Statistik Teori dan Aplikasi, Jl. 1 Ed 7, Jakarta : Erlangga, 25000.

[6] I. Sailah, Perlunya Tracer Study untuk Pendidikan Tinggi, Jakarta: Dirjen Belmawa Dikti, 2011.

[7] H.K. Schomburg, Handbook For Tracer Studies, International Center For Higher Education (INCHER-Kassel) Univ Kassel German, German, 2003 